КУЛЬТУРА, ОСВІТА І СУЧАСНЕ МИСТЕЦТВО В ДУХОВНОМУ ДОСВІДІ ОСОБИСТОСТІ УКРАЇНСЬКОГО СУСПІЛЬСТВА

Товтин H.I.

\title{
CULTURE, EDUCATION AND MODERN ART IN THE SPIRITUAL EXPERIENCE OF THE PERSONALITY OF THE UKRAINIAN SOCIETY
}

Tovtyn Nadiya

Спираючись на поняття духовності, в статті приділена увага специфічній ролі $i$ значенню видів мистецтва, розмаїттю тематичної та жанрово-стильової палітри сучасного українського мистецтва в духовному розвитку особистості.

В сучасних умовах слід враховувати важливість формування духовності підростаючого покоління та молоді. Тому необхідно осмислити, якою може і має бути духовність як особистісна якість. Усвідомлення поняття духовності повинно спонукати представників культури, освіти і мистецтва, релігії, публіщистів, політиків до вирішення даної проблеми.

Ключові слова: кіномистецтво, сучасна украӥнська література, театр, музичне мистецтво, духовність.

Based on the concept of spirituality, the article focuses on the specific role and significance of the types of art, the variety of thematic and genre-style palette of contemporary Ukrainian art in the spiritual development of the individual.

In today's context, the importance of forming the spirituality of the younger generation and youth should be taken into account. Therefore, it is necessary to understand what spirituality as a personal quality can and should be. Awareness of the concept of spirituality should encourage the representatives of culture, education and art, religion, publicists, politicians to solve this problem.

Key words: cinema, contemporary Ukrainian literature, theater, musical art, spirituality.

В попередньому випуску 2 (27), 2019 р. Міжнародного наукового журналу «ОСВITA I НАУКА» у статті на тему «Культура, освіта і сучасне мистецтво в духовному досвіді особистості українського суспільства» нами розглядалася проблема ролі освіти та сучасного мистецтва в житті соціально активної його частини - молоді. Ми дійшли висновку, що перебудова освіти на сучасному етапі нашого українського суспільства повинна створити умови для утвердження загальнолюдських цінностей, які можуть бути притаманні тільки духовно збагаченій людині. Духовні риси слід виховувати не в молодому віці, а 3 перших днів життя. Виховувати і навчати. Виховання і навчання є характерними складовими як для освіти, так і для мистецтва. Виховання і навчання завжди були двома сторонами єдиного процесу розвитку особистості через засвоєння і творче сприйняття цінностей духовної культури.

Сучасна масова культура розвинутих країн є однією з найбільш використовуваних та високоприбуткових індустрій соціальних послуг. Ми звикли вважати, що масова культура це в першу чергу товар. На тлі очевидного згасання традицій українського народного фольклору в художній культурі простежується тенденція зміни принципу іiі внутрішньої диференціації від соціально обумовлених жанрів до ієрархії комерційної рентабельності тих чи інших художніх феноменів.

В розвинутих країнах Заходу місце масової культури чітко визначене. В цих країнах ніхто не буде висувати голлівудський бойовик на премію «Оскар» або представляти його у конкурсній програмі Канського кінофестивалю. Споживач масової культури на Заході добре усвідомлює, що він споживає неякісне мистецтво. В даному випадку у споживача $€$ 
перспектива вибору: або йому дивитися бойовик по комерційному телебаченню, або переглянути високоякісний фільм, що пропонують мистецькі та освітні канали. На жаль, український глядач позбавлений можливості вибору. Адже високо-художне кіно на сьогоднішній день - велика рідкість на українських телеканалах або у кінотеатрах.

Серед всіх видів мистецтва комерційний фактор найяскравіше виявляється у кіно. На відміну від літератури, живопису, музики кінематографічне виробництво вимагає значних капіталовкладень на всіх етапах. Тому і розвиток кіномистецтва в цілому буде незрозумілим без врахування ринкової кон'юнктури. Так, виникнення такого специфічно маскультурного жанру як відеокліп пояснюється не стільки художньою логікою розвитку музики або кіно, а пошуками корпорацій нових засобів просування своєї продукції на ринок.

Фактично відеокліп виконує функцію рекламного ролика щодо артистів, які у ньому знімаються. Тому його завдання - пригорнути увагу будь-якими засобами, шокувати глядача. На екрані, як правило, ми спостерігаємо яскраву метушню кольорів, постійну зміну ракурсів. Навіть майстерний монтаж та велика кількість спецефектів не можуть приховати головне відсутність будь-якої художньої логіки у відеокліпі.

На відміну від відеокліпу, сам кінематограф виявився здатним розкрити свій гуманістичний потенціал, розробити власну художню мову. Кіно-мистецтво було не просто специфічним у XX столітті, але в певному сенсі само створило образ віку. Окрім того, кіно єдиний вид мистецтва, що спирається на великі фінансові й організаційні ресурси. Саме в історії розвитку художньої мови кіно та в іï головних результатах очевидні парадигми культури епохи.

Кіно - вкрай парадоксальний і суперечливий вид мистецтва. Як жодне інше мистецтво кіно може задокументувати реальність, проте цей документ, створений кіно, може бути найдостовірнішою фальсифікацією. Кіно народилося в атмосфері філософського, технічного, художнього і наукового підйому: теорія відносності і квантова фізика, різні напрямки психоаналізу, нові засоби масової комунікації, транспорт, поява грамофонних записів, радіо, телефону, виникнення художньої практики модернізму створили специфічну атмосферу, у який і народився кінематограф.

Людину можна показати доброю або злою, чесною або безчесною, - i все це за допомогою побудови кадру, особливо за допомогою сполучення і динаміки різних кадрів. Зрозуміло, що таке могутне знаряддя повинне було зацікавити тих, хто професійно займається технологією свідомості. Шалений, екстатичний монтаж стає у естетиці відеокліпа надлишковим і самодостатнім. Глядач розчиняється у вирі образів, де все можливо, який завгодно зміст може сполучитися з начебто далеким від цього змісту предметом (сценою) [2, c.4].

Все це, звичайно, не заперечує існування гуманістичного кіно, що спирається на національні традиції, філософські роздуми та духовні пошуки митців. Так фільми О. Довженко, з їх міфологічною і «шаманською» поетикою, спробами магічного відтворення (на новому рівні технології) всесвітньої картини Сил Життя, втілених у повітрі, воді, рослинності, світлі, еротичних енергіях відтворюють національну картину світу, відбивають духовні надбання українського народу. У О. Довженко та інших справжніх кіномитців монтаж спрямований на створення єдиного художнього образу світу. В авангардному та масовому кіно монтаж цей образ руйнує, нав'язуючи фрагментарний образ світу 3 випадковими зв'язками між його частинами.

«Я народився і жив для добра і любові». Такими словами відомий кінорежисер, письменник, великий патріот свого народу і син свого часу Олександр Довженко визначив своє життєве кредо. Кого не хвилюють його кіноповісті. Всесвітнє визнання його таланту незаперечне, бо ще майже п'ятдесят років тому на спеціальному конкурсі у Брюсселі серед дванадцяти найкращих фільмів усіх часів і народів названо було і його «Землю» [6]. 
Набагато краще виглядає ситуація в український літературі. Адже письменник, змушений шанувати матеріал, з яким він працює. Література по своїй природі приречена вирішувати вічні проблеми буття і саме у цьому запорука ії невмирущої сили.

Сучасна українська література - це більше, ніж література. Адже вона допомагає побачити картину нашого 3 вами світу таким, який він $\epsilon$ зараз. Серед письменників сьогодення вже $\epsilon$ навіть «живі класики» [1].

В останні роки досить помітною є тенденція до оновлення естетичних принципів романного епосу в українській літературі, зумовлена багатьма соціально-психологічними чинниками. Серед них - гострота і різноманітність морально-етичних проблем, динамічність суспільної та індивідуальної свідомості, зрештою, проблема збереження індивідуальності у масовому суспільстві, подолання «відчуженості», уміння віднаходити втрачені смисли та знакові символи існування.

Визначальна роль у розширенні тематичної та жанрово-стильової палітри сучасної української прози належить зростанню філософсько-інтелектуального потенціалу літератури, який важко уявити без постаті Валерія Шевчука - одного 3 найцікавіших письменників сучасності. Це творець нового для української літератури типу роману - роману філософського насичення, який органічно синтезує філософські віяння (зокрема сковородинські) і глибинні пласти українського фольклору та міфології. Щодо останнього, то особливо важливим видається питання трансформації письменником у своїх творах традиційних міфологічних образів та мотивів в русло сучасних ідейно-естетичних та морально-філософських проблем.

Називаючи конкретні твори молодих авторів, важко оцінити маштаб кожної окремої постаті. Імена Оксани Забужко, Юрія Андруховича, Юрія Винничука, Ірен Роздобутько, Сергія Жадана та ін. сьогодні відомі не тільки в Україні. Проте духовний потенціал мистецтва легше продемонструвати на творах, що стали вже живою класикою.

Величний образ собору, цього незвичайного дива, став головним центром роману П. Загребельного «Диво». Софія Київська схвилювала письменника, який назавжди визначив себе як романіст сучасної теми. П. Загребельний змусив себе ще раз звернутися, але вже 3 позиції сьогоднішнього дня, до далекої і сивої історії. І результатом таланту митця став твір, який вражає своєю незвичайно несподіваною побудовою, зухвалим перехрещуванням часів $\mathrm{i}$ епох, яке впадає в очі після прочитання вже перших сторінок.

Духовність бере початок з прадавніх коренів нашого роду, про який весь світ дізнався, слухаючи чарівний голос України в дзвонах куполів величного Софіївського собору, збудованого десять століть тому. Стоїть він і досі під небом історії як велич українського народу, як його мудрість і сила, талант і слава, як символ духовного єднання нації.

Перед читачами постають глухі грані між темами сучасності та історії, розгортаються розмови про духовні та моральні начала людини, нове й старе в національному характері, про ставлення до минулого, спадкоємність поколінь, вічні загальнолюдські питання життя i смерті, минущого і вічного. Бо осмислювати історію - то дбати про майбутнє!

Історія народу, на думку П. Загребельного, є сумою прагнень, дій і жертв багатьох поколінь, що жили в різні періоди на землі, і тому кожний народ має на собі печать духовної сили або слабкості тих, хто творив його історію. Змістом роману «Диво» письменник доводить, що наші предки були не лише умілими майстрами, а й людьми високої духовної культури. І це, передовсім, полонить читача, западає в душу.

Чи можна втекти від краси, побачивши іiі бодай раз? - ставить автор запитання. Чи можна іiї знищити? Нi! I таким незнищенним та вічним у своїй величі та красі є Софія. «Цей собор вже $з$ першого дня його існування, певно, мало хто вважав за житло для Бога. Він сприймався як надійний притулок людського духу. Тут відразу затаївся дух громадянства i мудрості тих, хто вибудовував державність Київської Русі. Може тому й боялися звинувачень в богохульстві усі ті хани, князі, королі, що налітали в різні часи на Київ і сплюндрували собор Софії, і кожен намагався зітерти його з земної поверхні. Але собор стояв несхитно, 
вічно, так, - ніби небудований був, а виріс із щедрот київської землі, став її продовженням, гучним іiї криком, іiї співом, мелодією, барвою. Диво!»

Духовні скарби давнини, що стали вічним джерелом духовності сьогодення, захищає мистецтвознавець двадцятого століття Гордій Отава. Саме він у полеміці з німецьким професором Шпурре відстояв ідею первісності культури українського народу, ціною свого життя зберігши від розкрадання фашистами творінь прадавнього генія. А об'єднуючою силою між поколіннями, між епохами, і не тільки минулими та сьогоднішніми, а й прийдешніми, виступає Софія Київська.

Незаперечною класикою стала й творчість Ліни Костенко. Михайло Слабошпицький назвав «Марусю Чурай» Ліни Костенко «енциклопедією життя українського народу середини XVII сторіччя». Так, - це енциклопедія народних звичаїв, традицій i, звичайно ж, народних характерів, типів.

Одним із центральних образів твору є образ української дівчини Марусі Чурай, яка виступає як символ усієї України доби козацьких воєн за своє звільнення. Саме через образ Марусі автор вводить нас в духовний світ наших предків, розкриває забуті сторінки історії, вчить мужності, совісті, пробуджує почуття власної гідності. Маруся Чурай - це образ взятий з народу, і так майстерно оспіваній Ліною Костенко для народу.

Різні жанри і види мистецтва користуються різною популярністю. Так, живопис знаходиться у вкрай занедбаному стані. Причина втрати інтересу до українського образотворчого мистецтва - у модернізмі і авангардизмі, які сповідують сучасні художники.

Заслуговує на увагу творча спадщина Леся Курбаса - представника українського театру. Адже до останніх років залишилися живими актори курбасівського «Березіля», які й виступали носіями традиції. Актор як метафізична проблема - це, з одного боку, проблема співвідношення в ньому сакрального і профанного, проблема автономності і домінанти першого. Але є й інший, глибший аспект цієї проблеми, а саме: художня культура може виступати суб'єктом Богопізнання, особливо у ситуації напруженого духовного простору, $\mathrm{i}$ тоді художня культура на шляхах самоорганізації вказує нам героя - в нашому випадку актора, в якому власне художня культура та їі найближча ніша (іноді - суспільство в цілому) усвідомлюють свою, хай крихку, але безпосередню причетність до Бога.

Курбас створив національний модерний театр, який позв'язав наше минуле - через пам'ять про містерію, через національно-генетичну культурну пам'ять про Київську Русь $\mathrm{i}$ українське Бароко, - 3 нашим завтра. Головним мірилом в цьому театрі була Людина 3 iіi увіковічненим пошуком духовності.

Багато що Курбасу вдалося випередити. Уроки театру Курбаса звернені до нас, кінець XX - поч. XXI ст. Пошуки «сакрального життя людського духу» Сжи Гротовського, «ескіз» нової культури у Брука, інтелектуальна арлекінада Федеріко Фелліні, мистецтво трагічної символіки у притчах Бергмана, «прадавня магічна дієвість» слів Антонена Арто, відсилають нас до витоків східноєвропейського авангарду i, зокрема, до курбасівського театру перетворення («Преображення»), 3 його містеріальністю, що надає роздумам про людину 3 їі відчуттям «вічного», одночасно високого й профанного, серйозного i балаганного, з можливістю перетлумачити буденне через кристал фантастичного [3].

Барочна українська естетика відроджується сьогодні і у музичних жанрах. Жвавий інтерес слухачів викликає українська духовна музика, яка не тільки виконується на концертах, але i стає зразком для сучасних композиторів. Багатомовність i багатонаціональність форм сповідування Бога - головна ознака історичної Церкви. Вона походить від апостольського прославлення Бога різними мовами у день П'ятидесятниці: «I сповнилися всі Духом Святим і почали говорити іншими мовами, ... зібрався народ і прийшов у збентеження; бо кожний чув їх, що говорять його мовою» (Діян. 2, 4-6). Це національне розмаїття оспівування і $є$ історичною умовою Вселенської Церкви.

Надзвичайне мелодичне багатство, кантилена, що йде від чистої душі і глибокого розуміння кожного слова, є наріжним каменем стилю вокально-хорової, співацької школи 
України. Молитва, як стан душі, неминуче змінює саму людину, накладаючи особливий відпечаток на всю іiі творчість, підносячи іï до вершин одухотвореності. Молитва суттєво впливає на тембр, звук голосу, надаючи йому благородства і вишуканості. Саме тут слід шукати джерела притаманних українському народові співучості, рідкісного мелодизму, свободи вокалізації, природності звуковідтворення.

Саме Літургія сформувала особливий тип світосприйняття, у відповідності з яким світ є живим єдиним літургійним організмом, де «небеса проповідують Славу Божу і про справи Його віщає твердь» (Пс. 19, 2). До неї як до основи основ століттями несли люди творчі дари своїх сердець, натхненні піснеспіви своїх душ. В іiі музичній тканині зосереджено всю можливу красу, філософську, богословську мудрість, глибину думки.

Незаперечним $є$ вплив Літургії на довколишній світ. Створені у момент найвищого духовного піднесення піснеспівам притаманні ознаки надбуття, справжньої високої одухотвореності. Прекрасна квітка української Літургії $є$ коштовною окрасою у вінку християнської музичної культури. Принесена українським народом, його кращими синамикомпозиторами до підніжжя Храму Господнього, вона несе навколишньому світові радість, зігріває серця слухачів, об'єднує і наповнює їх любов'ю, миром, надихаючи на нові творчі досягнення.

Саме 3 цих особистісних почуттів народжуються такі моральні цінності, як обов'язок, вірність, гуманність, волелюбність, подяка і т.д. Мистецтво нерозривно пов'язане зі свободою. Для того, щоб людина мала переконання, їй необхідна свобода. Тільки вільна людина може пережити «акт совісті». Позбавлена волі людина духовно мертвіє. Мистецтво $\epsilon$ «духовним повітрям» для людини [4].

Таким чином: необхідна кардинальна реформа освіти, як загальної середньої так i вищої. Потрібно терміново оновити той зміст, який вкладається у поняття «світська освіта» $\mathrm{i}$ привести його у відповідність до європейських стандартів. Адже в дуже багатьох європейських країнах Церква відокремлена від держави, а школа - від Церкви, але ніде це не означає ігнорування і Церкви і християнського виховання в навчальних закладах. Хоча законодавчо Церква відокремлена від держави i освіти, іiї неможливо відокремити від українського суспільства. Держава має чітко визначити - християнські моральні цінності повинні стати одними 3 головних у освітньо-виховному процесі. Держава не повинна лишатися осторонь від цих процесів і вона не може зняти з себе моральної відповідальності за рівень духовно-моральної культури українського суспільства. Усе наше суспільство, а особливо молодь, дедалі більше потребує таких рис як доброта, людяність, чуйність, милосердя, смирення, відповідальність, порядність.

Загально визначено, що мистецтво розвиває всебічну універсальну людську здібність, яка реалізується в будь-якій сфері людської діяльності і пізнання - і в освіті, і в політиці, і в побуті. Вища форма духовного відношення людини до світу - любов. Любов - суть самого життя. Саме любов пов'язує воєдино Істину, Добро і Красу. Однією з форм цього синтезу є мистецтво, у цьому його сутність. А якщо мистецтво справді співпадає зі своїми сутнісними характеристиками, воно завжди буде сучасним і актуальним.

\section{Список використаних джерел}

1. Двадцять сучасних українських письменників, яких варто прочитати [Електронний pecypc]. - Режим доступу: https://gloss.ua/https://gloss.ua/citynews/ 87696-24-suchasnihukrajinskih-pismenniki-yakih-varto-prochitati.

2. Добринська Н. Яку культуру молодь обирає і яку культуру втілює? / Н. Добринська // Вісник МАУП. - 1998. - № 4-5. - С.4.

3. Корнієнко Н. М. Лесь Курбас: репетиція майбутнього / Н. М. Корнієнко. - К.: Факт, 1998. - 469 c.

4. Суханцева В. К. Музыка как мир человека. От идеи вселенной - к философии музыки / В. К. Суханцева. - К.: Факт, 2000. - 176 с. 
5. Шрамко О. І. Культура - Духовність - Нація: науково-методичний збірник. Вип. 1 / ред. кол.: В.В.Бєлікова, І.В.Могілей, О.І.Шрамко. - К.: Гроно, 2005. - С.8-9.

6. Я народився і жив для добра і любові. До 125-річчя з дня народження О. Довженка [Електронний ресурс]. - Режим доступу: http://dspu.edu.ua/biblioteka/ 2019/09/05/\%d1\%8f\%d0\%bd\%d0\%b0\%d1\%80\%d0\%be\%d0\%b4\%d0\%b8\%d0\%b2\%d1\%8 $1 \% \mathrm{~d} 1 \% 8 \mathrm{f}-$

\section{References}

1. Dvadtsyat' suchasnykh ukrayins'kykh pys'mennykiv, yakykh varto prochytaty [Twenty modern Ukrainian writers worth reading]. [online] Available at: https://gloss.ua/https://gloss.ua/citynews/87696-24-suchasnih-ukrajinskih-pismenniki-yakihvarto-prochitati.

2. Dobryns'ka, N., 1998. Yaku kul'turu molod' obyraye i yaku kul'turu vtilyuye? [What kind of culture does the youth choose and what culture does it embody?]. MAUP Herald, 4-5, p. 4.

3. Korniyenko, N.M. 1998. Les' Kurbas: repetytsiya maybutn'oho [Les Kurbas: rehearsal of the future]. Kiev: Fact.

4. Sukhantseva, V.K. 2000. Muzyka kak myr cheloveka. Ot ydey vselennoy - k fylosofyy muzyky [Music as the world of man. From the idea of the universe to the philosophy of music]. Kiev: Fact.

5. Shramko, O.I.; Byelikova, V.V., Mohiley, I.V., Shramko, O.I. eds., 2005. Kul'tura Dukhovnist' - Natsiya [Culture - Spirituality - Nation], 1, pp. 8-9.

6. Ya narodyvsya i zhyv dlya dobra i lyubovi. Do 125-richchya z dnya narodzhennya O. Dovzhenka [I was born and lived for good and love. To the 125th anniversary of $\mathrm{O}$. Dovzhenko's birth]. [online] Available at: http://dspu.edu.ua/biblioteka/ 2019/09/05/\%d1\%8f\%d0\%bd\%d0\%b0\%d1\%80\%d0\%be\%d0\%b4\%d0\%b8\%d0\%b2\%d1\%8 $1 \% \mathrm{~d} 1 \% 8 \mathrm{f}-$.

УДК 378:373.3.011.3-051:372.32:373/.3/.5(477)

DOI:10.31339/2617-0833-2020-1(28)-160-165

\section{ПРОФЕСІЙНА ПІДГОТОВКА МАЙБУТНІХ УЧИТЕЛІВ ПОЧАТКОВОЇ ШКОЛИ ДО СТВОРЕННЯ ОСВІТНЬОГО СЕРЕДОВИЩА НОВОЇ УКРАЇНСЬКОЇ ШКОЛИ}

Фенцик О.М., Атрощенко Т.О., Пинзеник О.М.

\section{PROFESSIONAL TRAINING OF FUTURE PRIMARY SCHOOL TEACHERS FOR THE CREATION OF EDUCATIONAL ENVIRONMENT OF A NEW UKRAINIAN SCHOOL}

Fentsyk Oksana, Atroshchenko Tatiana, Pinzenik Olena

'У статті автори наголошують на необхідності удосконалення професійноі підготовки компетентного вчителя початкової школи. Окреслюють напрями, умови удосконалення підготовки професійно компетентного вчителя початкової загальноосвітньої школи у закладах вищої освіти відповідно до сучасних вимог Нової украӥнської школи,.

Ключові слова: професійна підготовка, професійна компетентність, нова украӥнська школа, інноваційна діяльність, освітнє середовище.

The authors of the article have emphasized the need to improve the professional training of a competent primary school teacher who is able to design, create a comfortable educational and cognitive educational environment, ready to carry out assessment, reflection and adjustment of the 